International Journal of Advanced Chemistry, 9(1) (2021) 8-11
International Journal of Advanced Chemistry
SPC
Website: www.sciencepubco.com/index.php/IJET
Research paper

\title{
Comparative analysis of ascorbic acid content of three varieties of apple fruit sold in Lafia open markets, north central Nigeria
}

\author{
Timothy M. Akpomie ${ }^{1 *}$, Abel U. Augustine ${ }^{1}$, Samuel E. Anwani ${ }^{1}$, Benjamin I. Aandaka ${ }^{1}$ \\ ${ }^{1}$ Department of Chemistry, Faculty of Science, Federal University of Lafia, P.M.B 146 Lafia, Nigeria \\ *Corresponding author E-mail: timothy.akpomie@ science.fulafia.edu.ng
}

\begin{abstract}
Ascorbic acid, also known as vitamin C, is a water-soluble vitamin which helps to boost the immune system, fight against infectious diseases, aids iron absorption and formation of collagen in humans and other animals. The ascorbic acid content of three varieties of apples (Red Delicious, Granny Smith and Golden Delicious apples) sold in Lafia, Nasarawa State, Nigeria was investigated using the iodometric titration method for comparative reasons. The results obtained showed the concentrations of the ascorbic acid in all three varieties of the fruit to be not only different but statistically so. The concentration of the analytes in order of increasing magnitude is; Golden Delicious $(22.83 \mathrm{mg} / 100 \mathrm{~g})$, Granny Smith $(29.26 \mathrm{mg} / 100 \mathrm{~g})$ and Red Delicious $(38.63 \mathrm{mg} / 100 \mathrm{~g})$. Though the differences in the respective concentration of the fruits were statistically significant ( $<<0.05$ ), these observed differences may not just be a function of the fruit variety alone but also on other possible reasons attributable to the impact of temperature, growing season, storage, shipping conditions and even post-harvest number of days as well as the maturity of the respective apple variety at the time of harvest prior to analysis. Comparatively, the analysis indicated that the three apple varieties are varied in ascorbic acid content but are all good sources vital for healthy living.
\end{abstract}

Keywords: Antioxidant; Apple; Ascorbic Acid; Comparative; Iodometric Titration.

\section{Introduction}

L-Ascorbic Acid (L-threo-hex-2-enono-1,4-lactone, ascorbate), also called vitamin C, is a water-soluble, antioxidant vitamin. Excess consumption of vitamin $\mathrm{C}$ does not cause much health hazards but can easily be excreted from the body. If the level is extremely high, this can result to severe diarrhea (Julia et al, 2010). The ascorbic acid is an essential antioxidant molecule in plants and animal which functions as a cofactor in many enzymes (Fenech et al, 2019). It also helps in activating the immune response, iron absorption and it aids the formation of collagen (a protein that gives structure to bones, cartilages, muscles, and blood vessels) and many other metabolic activities. In animals, Vitamin C contributes to wound healing and it prevents bleeding from the capillaries (Aurelia et al, 2011). According to Health Canada, children ages 1-3 require $15 \mathrm{mg} /$ day, adult females $75 \mathrm{mg} /$ day, and adult males need $90 \mathrm{mg} / \mathrm{day}$ (Julia et al, 2010).

Lack of vitamin $\mathrm{C}$ is known to have a number of detrimental health effects. One very important effect is the development of scurvy. Many animals have the capacity to synthesize ascorbate in the liver or in the kidney while non-human primates, guinea pigs and birds have lost this ability due to the accumulation of mutations in the coding sequence of the last committed enzyme of the pathway (L-gulono-1,4lactone oxidase, GULO) (Fenech et al, 2019). Dietary changes with the inclusion of abundant fruits and vegetables in the diet resulted in the loss of selective pressure to keep the pathway functional (Macknight et al, 2019). This process can also result in the development of scurvy. The primary sources of Vitamin C include blackcurrant, citrus fruit, leafy vegetables, tomatoes, apples, green and red peppers. Due to the reductive properties of vitamin C, it serves as antioxidants in food and drinks (Pisoschi et al, 2009).

Vitamin $\mathrm{C}$ undergoes oxidation reaction and is easily affected by heat and light as well as the presence of heavy metal cations (Pisoschi et al, 2011). The content variation commonly observed in vitamin $C$, serves a major reason why it is used as a quality indicator in food products, thereby promoting its antioxidant properties (Popa et al, 2010).

Methods for determining the Vitamin C content in fruits involves direct titration with iodine solution, titration with dichloroindophenol solution, using capillary electrophoresis with ultraviolet-visible, high performance liquid Chromatography (HPLC) and enzymatic method. The determination of vitamin $\mathrm{C}$ concentration involves iodine and iodate solution in a redox titration method. When iodine solution is a titrant, vitamin $\mathrm{C}$ is oxidized to form dehydroascorbic acid while the iodine is reduced to iodide ions. When all the vitamin $\mathrm{C}$ has finished, the excess iodine solution will react with starch solution to form blue-black color as the endpoint.

Apples (Malus domestica) ranks as one of the most cultivated fruit across the world, especially in temperate countries. It is a major source of vitamin $\mathrm{C}$ and a fruit which can be eaten directly from the tree or stored for up to a year. Apples can be processed into juice, sauce and slices. They are useful in production of wine and other consumable products. While there are thousands of different types of apples in the world, many types of apples are great for cooking, too. Their culinary versatility shows in many ways: Apples work in all-American or 
French dishes, and in kid-friendly or sophisticated treats as well as drinks. According to (Hyson, 2011) there are over 75 varieties of apples word-wide. These varieties represent over $60 \%$ of the world's production. Delicious is the most important cultivar grown, followed by 'Golden Delicious', 'Granny Smith', 'Fuji' and 'Gala'.

(Boyer et al, 2004) reported that apple contains phytochemicals which contribute to healthy body functions. Report also indicated that intake of apples can reduce the risk of coronary artery disease, lung cancer, asthma and diabetes. Based on the diversity of today's market place, the large varieties of apples have been reduced to just eleven. These varieties are tried-and-true favorites in the United States. The eleven varieties are; Jonagold, Cameo, Empire, McIntosh, Fuji, Cortland, Gala and Braeburn Apple. Others are; Granny Smith, Golden Delicious and Red delicious apples (Sung, 2018). This research investigated the ascorbic acid content of the later three varieties.

i) The Granny Smith Apple:

This is the apple once used to represent Apple Records. It is a favorite variety, widely grown, sold and eaten in the UK. It is also noted as common pie apple, lime green in color and is extremely tart.

ii) The Golden Delicious Apple is one of the most popular varieties in the world. Due to its regular size, even color and storage qualities, the fruit is widely sold commercially. It has a uniform light green-yellow coloration, very sweet and a good pollinator.

iii) The Red Delicious Apple is unmistakable for its acutely conic shape, dark red color and tell-tale bumps on the bottom. Its flavor is sweet and mild. This variety is not a choice for cooking or cider. Its original seedling is known as "Hawkeye". It was first marketed as "Delicious" or "Stark's Delicious," but name changed to "Red Delicious" a little over a century ago. Red Delicious has many sports and ranks as the world's most prolific apple.

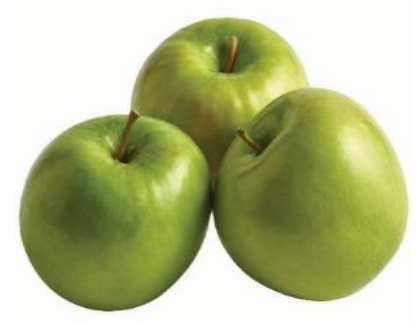

Fig. 1: Granny Smith Apple

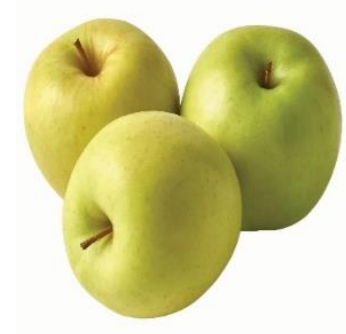

Fig. 2: Golden Delicious Apple.

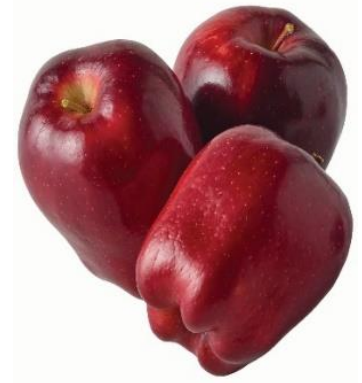

Fig. 3: Red Delicious Apple.

\section{Materials and methods}

\subsection{Sample collection}

Three different samples of fresh and ripped apples fruits; red delicious apple (red apple), granny smith (green apple) and golden delicious (golden apple) were bought in Lafia modern market in Lafia Local Government Area, Nasarawa State.

\subsection{Sample preparations}

Each of the three varieties of the apple samples collected were thoroughly washed and were cut into smaller pieces. The samples were blended using a mechanical blender to obtain the apple juice and labeled accordingly. A $10 \mathrm{~cm}^{3}$ portion of distilled water was added sequentially while the blending was in progress and the apple juice extract were collected. The juice extract obtained in the three different apples were decanted into a $100 \mathrm{~cm}^{3}$ volumetric flask and was made up to mark.

\subsection{Iodometric determination of vitamin c content in apples}

The juice extracts obtained $\left(20 \mathrm{~cm}^{3}\right)$ was measured into a $250 \mathrm{~cm}^{3}$ conical flask followed by the addition of $50 \mathrm{~cm}^{3}$ distilled water. Starch indicator solution $\left(2 \mathrm{~cm}^{3}\right)$ was added into the mixtures in drops. The solutions were titrated each in triplicates with $0.005 \mathrm{~mol} / \mathrm{L}$ of iodine solution until a dark blue-black coloration was observed and the vitamin $\mathrm{C}$ content was calculated using equations 1 and 2 below:

$\mathrm{MI}=$ Conc. of Ascorbic acid $\times \frac{1 \mathrm{~mole}}{176.12 \mathrm{~g} \text { of ascorbic acid }} \times \frac{1000 \mathrm{~mL}}{\mathrm{VI}}$

$\mathrm{CAA}=\mathrm{MI} \times \mathrm{VI} \times 176.12 \mathrm{~g}$ of Ascorbic acid

Where;

$\mathrm{CAA}=$ Conc of Ascorbic acid

MI= Mole of Iodine

$\mathrm{VI}=$ Volume of iodine

\section{Results and discussion}




\subsection{Result}

Table 1: Concentration of Ascorbic Acid (Mg/100g) in Varieties of Apple Fruits

\begin{tabular}{llllll}
\hline \multirow{2}{*}{ S/No } & \multirow{2}{*}{ Apple Variety } & Ascorbic Acid & 2 & 3 & Mean \pm SD \\
& Red Delicious & 1 & 45.23 & 34.03 & 36.63 \\
2 & Granny Smith & 28.33 & 31.00 & 28.46 & $38.63 \pm 5.86^{\mathrm{a}}$ \\
3 & Golden Delicious & 20.53 & 23.81 & 24.16 & $26.26 \pm 1.50^{\mathrm{b}}$ \\
\hline
\end{tabular}

Values labeled a, b, c, are statistically significant at $\mathrm{p}<0.05$

\subsection{Discussion}

Table 1 shows the different concentrations of the ascorbic acid content in the three varieties of apple fruits sold in Lafia market. From the results obtained, Red delicious apple has the highest concentration of ascorbic acid (38.63 g/100), followed by Granny smith apple (29.26 $\mathrm{mg} / 100 \mathrm{~g})$ and the least was Golden delicious $(22.26 \mathrm{mg} / 100 \mathrm{~g})$. Though the three varieties of apples studied showed different amount or concentration of ascorbic acid, statistical analysis (One-way ANOVA) showed that there was no significant difference at $95 \%$ confidence limit $(\mathrm{P}<0.05)$ between the measurements. The Ascorbic acid content in the three varieties of apple investigated in this study were higher than the values reported by (Gazdik et al, 2008) which had a vitamin C content ranging from 11 to $19 \mathrm{mg} / 100 \mathrm{~g}$.

Furthermore, the vitamin in Red delicious apple $(38.63 \mathrm{mg} / 100 \mathrm{~g})$ in this study is also higher than the values obtained in conventional (19.8 $\mathrm{mg} / 100 \mathrm{~g})$ and organic $(21.4 \mathrm{mg} / 100 \mathrm{~g})$ red delicious apples as reported by (Kariuk et al, 2010). (Kobus et al, 2020) reported the ascorbic acid content in Granny Smith apple to be $68.18 \mathrm{mg} / 100 \mathrm{~g}$ which was higher compared to the values obtained in this study. These variations observed in same species of the apple were probably as a result of the differences in storage temperatures they may have been exposed to. Several other studies showed that storage temperatures have greater impact on the ascorbic acid content loss in apples. For instance, (Batehelder, 1934) reported that Washington Delicious apples placed in storage at $32^{0} \mathrm{~F}$, for 6 months lost no ascorbic acid while apples stored at $45^{\circ} \mathrm{F}$, lost one-sixth of their ascorbic acid content the first 3 months and up to one-fourth during storage for 6 months.

The variation in the concentrations of ascorbic acid content in the species of apples investigated could also be attributed to factors other than temperature such as; growing season, storage, and shipping conditions (Kobus et al, 2020). These variations could also be attributed to the fact that ascorbic acid is susceptible to oxidation by atmospheric oxygen over time (Anebi et al, 2016), leading to the formation of dehydroxy-ascorbic acid. (Warman et al, 1997), reported that the mode of storage greatly affected the vitamin $\mathrm{C}$ content in cabbage and carrots. A study conducted by (Chassy et al, 2006) on organic and conventionally grown tomatoes and bell peppers for three years, found that environmental and growing conditions has a greater impact on the levels of Ascorbic acid content in them.

The dietary amounts of vitamin C recommended for adults according to dietary guidelines for Americans 2015-2020, are 75-90 mg per day. From the varieties of apples analyzed, the result showed that the apples are potential sources of ascorbic acid. They can contribute efficiently to amount needed for healthy living. From discussions already advanced, it is very lucid that same species of apples may not necessarily contain same quantity of ascorbic acid. The amount of ascorbic acid differs within and between species, and for the purpose of this study, the three varieties had different mean concentrations but these concentrations were not statistically different.

\section{Conclusion}

Analysis on the ascorbic acid content of the three varieties of apple sold in Lafia, Nasarawa state showed that all the apples analyzed were potential sources of Ascorbic acid. The result of the analysis revealed that Red Delicious apple contained more ascorbic acid content (38.63 $\mathrm{mg} / 100 \mathrm{~g}$ ) than Granny Smith and Golden Delicious apples with the vitamin content of $29.26 \mathrm{mg} / 100 \mathrm{~g}$ and $22.26 \mathrm{mg} / 100 \mathrm{~g}$ respectively. Though the concentration in the three varieties or species of apples are comparatively different, statistically, all three were found not to be different. The observed variations in the concentration of ascorbic acid between the three varieties were attributed to other factors like variations in temperature, growing season, storage, and shipping conditions. The Red delicious, Granny smith and Golden delicious apples were found to be good and rich sources of ascorbic acid and should be consumed on daily bases for the provision of daily dietary needs for optimal health especially the red delicious apple.

\section{Acknowledgement}

We are indeed grateful to the management and staff of the Chemistry laboratory of the Department of Chemistry, Federal University of Lafia for their commitment and prompt assistance during the experimental analysis of this research.

\section{References}

[1] Julia RE, Jeffrey RF and James KK (2010). Determination of the Vitamin C Content of Conventionally and Organically Grown Fruits by Cyclic Voltammetry. International Journal of Electrochemical Science. 5:1464 - 1474.

[2] Fenech M, Amaya I, Valpuesta V and Miguel AB (2019). Vitamin C Content in Fruits: Biosynthesis and Regulation. Frontiers in Plant Science. 9:1 21. https://doi.org/10.3389/fpls.2018.02006.

[3] Aurelia, MP, Aneta, P, Gheorghe, PN and Aurel, P (2011). Determination of Ascorbic Acid Content of Some Fruit Juices and Wine by Voltammetry Performed at Pt and Carbon Paste Electrodes. Molecules. 16:1349-1365. https://doi.org/10.3390/molecules16021349.

[4] Macknight RC, Laing WA, Bulley SM, Broad RC, Johnson AA, and Hellens RP (2017). Increasing ascorbate levels in crops to en-hance human nutrition and plant abiotic stress tolerance. Current Opinion Biotechnology. 44:153-160. https://doi.org/10.1016/j.copbio.2017.01.011.

[5] Pisoschi AM, Cheregi MC and Danet AF (2009). Total antioxidant capacity of some commercial fruit juices: electrochemical and spec-trophotometrical approaches. Molecules. 14:480-493. https://doi.org/10.3390/molecules14010480.

[6] Pisoschi AM and Negulescu GP (2011). Methods for Total Antioxidant Activity Determination: A Review. Biochemistry and Analytical Biochemistry. 1(1): 106 .

[7] Popa CV, Danet AF, Jipa S and Zaharescu T (2010). Determination of total antioxidant activity of wines using a flow injection method with chemiluminescence detection. Rev Chim (Bucharest). 61: 11-16.

[8] Hyson DA (2011). A Comprehensive Review of Apples and Apple Components and Their Relationship to Human Health. Advanced Nutrition. 2: 408-420 https://doi.org/10.3945/an.111.000513. 
[9] Boyer J and Liu R (2004). Apple phytochemicals and their health benefits. Nutritional Journal. 3:5. https://doi.org/10.1186/1475-2891-3-5.

[10] Sung E (2018). Different Types and Varieties of Apples. As viewed in https://www.epicurious.com/contributors/esther-sung

[11] Gazdik Z, Zitka O, Petrlova J, Adam V, Zehnalek J, Horna A, Reznicek V, Beklova M and Kizek R (2008). Determination of Vitamin C (Ascorbic Acid) Using High Performance Liquid Chromatography Coupled with Electrochemical Detection. Sensors. 8(11):7097-7112. https://doi.org/10.3390/s8117097.

[12] Kariuk JK, Julia RE and Jeffrey RF (2010). Determination of the Vitamin C Content of Conventionally and Organically Grown Fruits by Cyclic Voltammetry. International Journal of Electrochemical Science. 5:1464 - 1474

[13] Kobus Z, Kamil WN, Rafał N and Marek S (2020). Assessment of the Usefulness of the Twin-Screw Press in Terms of the Pressing Efficiency and Antioxidant Properties of Apple Juice. Processes. 8(101):1-16. https://doi.org/10.3390/pr8010101.

[14] Batehelder, EI (1934). Vitamin C in delicious apple before and after storage. Journal of Nutrition. 7:4-6. https://doi.org/10.1093/jn/7.6.647.

[15] Anebi, OP, Ugbe, AF, Igwe, CP and Odumu, OF (2016). Determination of Variation of Vitamin 'C' Content of Some Fruits and Vegetables Consumed in Ugbokolo After Prolonged Storage. Journal of Environmental Science, Toxicology and Food Technol-ogy. 10(7): 17-19

[16] Warman PR and Havard KA (1997). Yield, vitamin and mineral contents of organically and conventionally grown carrots and cabbage. Agriculture, Ecosystems and Environment. 61(2-3): 155-165 https://doi.org/10.1016/S0167-8809(96)01110-3.

[17] Chassy AW, Bui L, Renaud ENC, Van-Horn M and Mitchell AE (2006). Three-year comparison of the content of antioxidant micro-constituents and several quality characteristics in organic and conventionally managed tomatoes and bell peppers. Journal of Agric Food Chemistry. 54(21):8244-52 https://doi.org/10.1021/jf060950p. 